\title{
Miranda
}

Revue pluridisciplinaire du monde anglophone /

Multidisciplinary peer-reviewed journal on the English-

speaking world

15 | 2017

Lolita at 60 / Staging American Bodies

\section{Kokumo Noxid, Dub Truth}

\section{Eric Doumerc}

\section{QpenEdition}

\section{Journals}

Electronic version

URL: http://journals.openedition.org/miranda/10582

DOI: 10.4000/miranda.10582

ISSN: 2108-6559

\section{Publisher}

Université Toulouse - Jean Jaurès

\section{Electronic reference}

Eric Doumerc, "Kokumo Noxid, Dub Truth", Miranda [Online], 15 | 2017, Online since 19 September 2017 connection on 16 February 2021. URL: http://journals.openedition.org/miranda/10582 ; DOI: https:// doi.org/10.4000/miranda.10582

This text was automatically generated on 16 February 2021.

\section{$\Theta \Theta \Theta \Theta$}

Miranda is licensed under a Creative Commons Attribution-NonCommercial-NoDerivatives 4.0 International License. 


\title{
Kokumo Noxid, Dub Truth
}

\author{
Eric Doumerc
}

\section{REFERENCES}

Noxid, Kokumo. Dub Truth. Stourbridge: APS Publications, 2016. 127 pages, ISBN :

978-1536979947

1 Gerald Dixon, aka Kokumo, was born in Jamaica. He has lived in Birmingham for many years and is well-known as a dub poet, workshop facilitator and storyteller. For a few years he ran a "griottology" workshop at the Drum, the local arts centre in Aston which closed down recently, where he compered several events like the tribute to Louise Bennett in September 2006.

2 Kokumo visits Jamaica regularly and has worked with the noted dub poet Yasus Afari, releasing a CD single with him entitled "Set it Off". In 2006 Kokumo released a CD entitled Writing's on the Wall, recorded in Birmingham with local musicians. In 2017 his debut collection of poems, Dub Truth, was published by APS Publications, a small publishing house based in Stourbridge, in the West Midlands.

3 The title of the collection is an allusion to Kokumo Noxid's vision of dub poetry. In a recent email communication, he gave me his own definition of dub poetry:" The true essence of dub poetry is to inform and to invoke conscious responses to cultural and social norms. It must be the voice of the downtrodden". This definition is quite in keeping with the revolutionary thrust of dub poetry as it emerged in the 1970s with poets like Linton Kwesi Johnson, Mutabaruka and of course Oku Onuora.

4 Kokumo Noxid's Dub Truth can be seen as an example of traditional dub poetry or griot poetry.

5 There are several definitions of the word "griot": the strict definition which can be found in any dictionary and refers to the West African context, and a looser, more flexible definition found in books and articles dealing with the oral tradition in a more general sense. Strictly speaking, a griot is a travelling, itinerant musician and poet/ storyteller from West Africa or Senegambia. The Collins English Dictionary gives the 
following definition of the word "griot":" A member of a caste responsible for maintaining an oral record of tribal history in the form of music, poetry, and storytelling"(from the Free Online Dictionary). In The Rap Attack, David Toop quotes an excerpt from Savannah Syncopators: African Retentions In the Blues (1970) by Paul Oliver in which the art of the griot is summed up: "though he has to know many traditional songs without error, he must also have the ability to extemporize on current events, chance incidents and the passing scene. His wit can be devastating and his knowledge of local history formidable"(Toop 32).

6 A quick internet search will reveal that the word "griot" is today commonly used to refer to a variety of performance poets and poets or spoken word artists. For instance an article published in the Jamaican newspaper The Daily Gleaner article in November 2006 refers to the performance poet Seretse Small as a "griot with a guitar" (The Gleaner, 26 November 2006).

7 Kokumo Noxid's Dub Truth can be seen as a form of griot poetry inasmuch as the poet voices the concerns of his community and acts as its spokesman. What makes Noxid's collection unusual is that the poet widens the remit of traditional dub poetry to reach out to the African-American community, which leads to the birth of a transnational dub poetry.

8 The themes developed in Dub Truth are well in keeping with the traditional ethos of dub poetry and are often social and political. So we find poems dealing with the negative stereotyping Jamaicans are often burdened with abroad ("A One Jamaikan Dis"), life in Jamaica's working-class areas ("Dis Yah Pressha"), Pan-Africanism ("Garvey's Vision"), the limitations of independence ("In-Dependence Dance") and the persistence of mental slavery ("Enslaved"). The influence of traditional dub poetry is also visible in the intertextuality with reggae culture which characterizes this collection. Indeed the poem entitled "Natty Boo York" is reminiscent of Black Uhuru's "Chill Out", "Dis Yah Pressah" bears the influence of Sugar Minott's "Hard Time Pressure" and "De System" echoes Mutabaruka's poem of the same name.

The Jamaican oral tradition features heavily in this collection, as can be seen in the poem entitled "Maskittah" which is a modern reworking of an old Jamaican traditional song ("Mosquito One, Mosquito Two, Mosquito jump inna hot callaloo!"). Kokumo Noxid's version incorporates references to Chikungunya and the Zika outbreak before accusing the "big pharmaceutical compiniz" (Dub Truth 41) of making the most of this new market.

That said, Kokumo Noxid's poetry transcends the borders of traditional dub poetry to embrace African-American culture. The poem entitled "No Knock, In Cyber Space" updates in an ironic way Gil Scott-Heron's "No Knock", a poem that decried the tactics used by American policemen trying to search some premises without announcing their presence. Noxid's poem adapts this iconic piece to the digital age:

No Knock, if you think I'm scared

Come knockin' if you're brave

But triple lock your computer and smart phone

Because soon someone

May be hack-hackin'

And the next no-knocker

Ha, ha, ha!

Is for you (Dub Truth 13) 
11 Likewise, in "I Didn't Want to Call It Baltimore", the poet mentions the New York African-American poet Ngoma Hill as well as Randy Newman's "Baltimore" to insist on the theme of racial discrimination in America. The poem entitled "Killin' America" refers to the sad case of Sandra Bland, an African-American woman who died in custody after being arrested for a traffic offence but also ropes in the Flint, Michigan water contamination affair:

How long have you been killin' America

How many blood-soaked boots

Returned to doorsteps

I see killing is your intention

We will never forget Sandra Bland

You even poisoned water in Flint, Michigan (Dub Truth 58)

The poet thus sees himself as a kind of alternative newscaster or journalist whose role is to draw the public's attention to some serious issues. Kokumo Noxid's debut collection is thus a modern reinvention of dub/griot poetry, but within a global context which encompasses the African-American and even the American dimension. This transnational scope is what could make Kokumo Noxid's poetry different from other dub poetry collections. It is a type of poetry which has its place and which is much needed today.

\section{INDEX}

Keywords: dub poetry, griot, reggae

Mots-clés: dub poetry, griot, reggae

\section{AUTHORS}

\section{ERIC DOUMERC}

Maître de Conférences

Université de Toulouse-Jean Jaurès

doumerceric@neuf.fr 